\title{
Expression of Gap-Junctional Protein (Connexin 43 or $\alpha 1$ Gap Junction) is Down-Regulated at the Transcriptional Level during Adipocyte Differentiation of H-1/A Marrow Stromal Cells
}

\author{
Akihiro Umezawa* and Jun-ichi Hata \\ Department of Pathology, Keio University School of Medicine, 35 Shinanomachi, Shinjuku-ku, Tokyo 160, \\ Japan
}

Key words: gap junction/adipocyte/bone marrow/differentiation/stroma cell

\begin{abstract}
Bone marrow stromal cells are requisite for the proliferation of hematopoietic cells and communicate with each other via gap junctions. Marrow stromal cells expressed connexin 43, but not connexin 32 . H-1/A, a murine marrow stromal cell line, underwent adipocyte differentiation at confluence, and expressed the 3.0 kilobase mRNA species of connexin 43 before differentiation. H-1/A cells studied with the dye-transfer method showed gap-junctional communication with adjacent cells but lost this communication during differentiation. The connexin 43 transcripts in H-1/A cells were down-regulated before the expression of glycero-monophosphate dehydrogenase was induced. Loss of gap-junctional communication was regulated at the mRNA level of connexin 43 . Connexin 43 expression was down-regulated at the transcriptional level.
\end{abstract}

Gap junctions between cells are present in many tissues and in a wide range of species. Gap junctions are composed of protein channels that allow molecules with molecular weights of less than 1500 to pass directly from the inside of one cell to that of another $(16,17$, 21). Cells connected by gap junctions share many of their small molecules, hence gap junctions are clearly important in coordinating the activity of these cells and expressing a cell's individuality. cDNA for mammalian gap-junction proteins has been cloned, and it appears that there are tissue-specific gap-junctions $(4,19,24$, 39). The three Xenopus gap junction cDNAs have also been isolated and found to be expressed differentially during the development of Xenopus embryos $(10,11)$. Gap junctions have also been detected between mammalian marrow stromal cells in vivo by means of electron microscopy (36). In vitro, gap junctions have been observed in bone marrow cultures and cell lines by means of electron microscopy $(2,6,37,38)$ and the dye-transfer method $(30,31)$.

Intercellular communication via gap junctions is reported to be correlated with early embryogenesis, terminal differentiation and cell growth $(3,18,35)$. 3T3-L1 cells lose virtually all cellular communication when induced to differentiate into adipocytes (3). The induction of cell growth causes a transient reduction in communication in 3T3-L1 cells and is related to the tumor-promoting phorbol ester-induced modulation of cell-to-cell

\footnotetext{
* To whom all correspondence should be addressed.
}

and cell-to-substratum interactions $(25,26,27)$. Meanwhile, a marrow stromal cell line, $\mathrm{H}-1 / \mathrm{A}$, cloned from the bone marrow of C57/Bl mice spontaneously differentiates into adipocytes in vitro (13) and expresses a marrow stroma-specific antigen (1). $\mathrm{H}-1 /$ A cells contribute to granulopoiesis during the fibrocytic stage by producing colony-stimulating factor 1 (CSF-1) $(23,32)$. With the dye transfer method, $\mathrm{H}-1 /$ A cells in vitro were found to communicate with each other via gap junction $(30,31)$. Gap-junctional communication of $\mathrm{H}-1 / \mathrm{A}$ cells also decreases during adipocyte differentiation as in 3T3-L1 cells. However, the mechanism regulating loss of communication remains unknown. This study reports that the loss of gap-junctional communication is controlled at a connexin 43 transcriptional level and precedes the switching-on of the glycero-monophosphate dehydrogenase (GPD) gene during adipocyte differentiation of $\mathrm{H}-1 / \mathrm{A}$ stromal cells.

\section{MATERIALS AND METHODS}

Cell culture. H-1/A cells were routinely cultured with Fischer's medium (GIBCO, Grand Island, N.Y.) supplemented with $10 \%$ horse serum (Irvine Sci., Santa Ana, Calif.), penicillin, and streptomycin. The cultures were incubated at $33^{\circ} \mathrm{C}$ in an atmosphere of $5 \%$ carbon dioxide. In certain cases, $\mathrm{H}-1 / \mathrm{A}$ cells were also treated with $200 \mathrm{U} / \mathrm{ml}$ or $1,000 \mathrm{U} / \mathrm{ml}$ of cachectin/TNF (Genzyme Co., Boston, MA) at confluence and 6 days after confluence. To estimate adipocyte differentiation, dishes were fixed with $10 \%$ buffered neu- 
tral formalin and stained with $0.5 \%$ Oil Red $\mathrm{O}$ in propylene glycol.

RNA blot analysis. Fresh unsupplemented medium, or medium containing $200 \mathrm{U} / \mathrm{ml}$ or $1,000 \mathrm{U} / \mathrm{ml}$ of cachectin /TNF was added to semiconfluent or confluent layers of $\mathrm{H}$ $1 /$ A cells. After incubation for 12,24 , or 72 hours, cells were harvested for RNA blot analysis. RNA was prepared from cultured cells by homogenization in guanidinium isothiocyanate, followed by centrifugation over a cesium chloride cushion (5). The RNA was then electrophoresed in a $1.0 \%$ agarose gel, transferred to a nylon filter (Du Pont Company NEN Products), and hybridized with cDNA inserts labeled with ${ }^{32} \mathrm{P}$ $\mathrm{dCTP}$ by the random-primer method (9) at $65^{\circ} \mathrm{C}$ for $14-16$ hours in buffer containing $5 \times \mathrm{SSPE}[1 \times \mathrm{SSPE}$ is $0.15 \mathrm{M}$ $\mathrm{NaCl}, 10 \mathrm{mM} \mathrm{NaH} \mathrm{PO}_{4} / \mathrm{Na}_{2} \mathrm{HPO}_{4}(\mathrm{pH} 7.4), 1 \mathrm{mM}$ EDTA], $5 \times$ Denhardt's solution ( $1 \times$ Denhardt's solution is $0.02 \%$ Ficoll, $0.02 \%$ polyvinylpyrrolidone, $0.02 \%$ BSA), $0.02 \%$ poly(A), and $1 \%$ SDS. The blots were washed with $2 \times \mathrm{SSC}$ $(1 \times \mathrm{SSC}$ is $0.15 \mathrm{M} \mathrm{NaCl}, 0.015 \mathrm{M}$ sodium citrate, $\mathrm{pH} 7.4)$ containing $1 \% \mathrm{SDS}$ at room temperature and $65^{\circ} \mathrm{C}$. Final washings were performed with $0.1 \times \mathrm{SSC}$ containing $0.1 \% \mathrm{SDS}$ at $65^{\circ} \mathrm{C}$. The blots were exposed to $\mathrm{X}$-ray film at $-80^{\circ} \mathrm{C}$ using an intensifying screen.

The connexin 43 was a 1.4 kilobase $(\mathrm{kb})$ EcoRI fragment from G2A (4). The connexin 32 was a $1.5 \mathrm{~kb}$ EcoRI fragment (24). The GPD probe was a $0.9 \mathrm{~kb}$ EcoRI fragment of $\mathrm{pL} 10.9$ (28). The actin probe was a $6.8 \mathrm{~kb}$ EcoRI fragment of pSP62PL (15). With the use of this $\alpha$-actin DNA, $\beta$-actin mRNA was detected by RNA blot analysis to check the total amount of RNA loaded. Quantification of RNA hybridized to each probe was determined by densitometry of bands using Quick Scan R \& D (Helena Laboratories).

Communication assay. Intercellular transfer of fluorescent Lucifer Yellow CH (Sigma, ST Louis, USA) was measured after direct microinjection of the dye into a cell under a phase-contrast microscope and observation of its transfer to neighboring cells under a fluorescence microscope. Microinjection was carried out using a micromanipulator (Narishige Co., Tokyo, Japan). A 10\% solution of Lucifer Yellow CH in a $0.3 \mathrm{M}$ lithium chloride solution was transferred to a glass capillary needle which was prepared from a capillary tube using an Automatic Magnetic Puller (Narishige Co., Tokyo, Japan). H-1/A cells were impaled with capillary needles close to the nucleus, and dye was injected by manual pressure. The transfer of dye into surrounding cells was monitored under a phase-contrast fluorescence microscope after injection. The percentage of first-order neighbors in contact with the injected cell and the number of fluorescent cells was recorded after each injection.

Nuclear run-off transcription assay. Run-off transcription assays were performed using a modification of the method described by Groudine et al. (12). Cells were harvested from 4 dishes by scraping with a rubber policeman. Subsequent steps were performed at $4^{\circ} \mathrm{C}$. The cells were washed in phosphatebuffered saline and lysed by vortexing in NP-40 lysis buffer
[10 mM Tris- $\mathrm{HCl}$ (pH 7.4), $10 \mathrm{mM} \mathrm{NaCl}, 3 \mathrm{mM} \mathrm{MgCl}_{2}, 0.5 \%$ NP-40]. The lysates were incubated on ice for 5 minutes, resuspended in glycerol storage buffer [50 mM Tris- $\mathrm{HCl}(\mathrm{pH} 8.0)$, $40 \%$ glycerol, $5 \mathrm{mM} \mathrm{MgCl}_{2}, 0.1 \mathrm{mM}$ EDTA], and stored as a nucleus fraction at $-80^{\circ} \mathrm{C}$ in $200 \mu \mathrm{l}$ aliquots. The nucleus fraction was mixed with $200 \mu$ l of $2 \times$ reaction buffer $[10 \mathrm{mM}$ Tris- $\mathrm{HCl}(\mathrm{pH} 8.0), 5 \mathrm{mM} \mathrm{MgCl}_{2}, 0.3 \mathrm{M} \mathrm{KCl}$ and $1 \mathrm{mM}$ each of ATP, CTP and GTP] plus $10 \mu \mathrm{l}\left[\alpha^{3}{ }^{32} \mathrm{P}\right] U T P(800 \mathrm{Ci}$ $/ \mathrm{mmol}$ ) and incubated for 30 minutes at $30^{\circ} \mathrm{C}$ with shaking. After incubation, nuclei were pelleted in a microfuge, resuspended in $300 \mu \mathrm{l}$ of $0.5 \mathrm{M} \mathrm{NaCl}, 50 \mathrm{mM} \mathrm{MgCl}_{2}, 2 \mathrm{mM} \mathrm{CaCl}_{2}$, and $10 \mathrm{mM}$ Tris- $\mathrm{HCl}(\mathrm{pH} \mathrm{7.4)}$, with $200 \mathrm{U}$ of DNase I (RNase-free, Pharmacia), and incubated for 30 minutes at $37^{\circ} \mathrm{C}$. After the addition of $200 \mu \mathrm{l}$ of $5 \%$ SDS, $0.5 \mathrm{M}$ Tris- $\mathrm{HCl}(\mathrm{pH}$ 7.4), $0.125 \mathrm{M}$ EDTA and $10 \mu \mathrm{l}$ of $20 \mathrm{mg} / \mathrm{ml}$ proteinase $\mathrm{K}$, nuclei were vortexed thoroughly and incubated for 30 minutes at $40^{\circ} \mathrm{C}$. The reaction mixture was extracted three times with phenol/chloroform and the radiolabeled RNA was precipitated with an equal volume of $100 \%$ isopropanol. The precipitate was resuspended in $100 \mu \mathrm{l}$ of $10 \mathrm{mM}$ Tris- $\mathrm{HCl}$ (pH 8.0), 1 mM EDTA and $0.1 \mathrm{M} \mathrm{NaCl}$, and loaded onto the Sephadex G-50 column (Boehringer Mannheim) to remove unincorporated nucleotides. An equivalent amount of radiolabeled RNA $\left(2 \times 10^{6}\right.$ c.p.m) from each cell was hybridized to denatured DNA probes ( $>2 \mu \mathrm{g}$ each), and immobilized to nylon filter paper in $2 \mathrm{ml}$ of hybridization buffer [ $5 \times \mathrm{SSPE}, 5 \times$ Denhardt's solution, $0.02 \%$ poly(A) and $1 \% \mathrm{SDS}$ ] for 36 hours at $65^{\circ} \mathrm{C}$ after preincubation in hybridization buffer for 1 hour at $65^{\circ} \mathrm{C}$. The filters were washed in $2 \times \mathrm{SSC}$ and $1 \%$ SDS twice at $65^{\circ} \mathrm{C}$. The filters were exposed to X-ray film at $-80^{\circ} \mathrm{C}$.

\section{RESULTS}

Marrow stroma-derived $\mathrm{H}-1 /$ A cells had a fibroblastlike morphology and no adipocytes developed until they reached confluence. The manner of adipocyte differentiation of $\mathrm{H}-1 / \mathrm{A}$ cells has been described previously $(23,31,32)$. In the $\mathrm{H}-1 / \mathrm{A}$ culture, $35.6 \%$ of the cells on the third day, $51.0 \%$ on the sixth day and $59.0 \%$ on the seventh day after confluence differentiated into adipocytes, while only $1.3 \%$ of the cells of another subline, H-1/D, did so on the seventh day after confluence.

To investigate the expression of gap-junction genes, blot hybridization of stromal cell RNA was performed with probes of connexin 43 and connexin 32 cDNA. Distinct mRNA bands of $3.0 \mathrm{~kb}$ were detected in all the marrow stromal cell lines previously reported (33) when tested with the connexin $43 \mathrm{cDNA}$ probe, although no bands were observed in any of the cells when tested with a probe of connexin 32 (data not shown). In order to determine the level of connexin 43 transcripts in $\mathrm{H}-1 / \mathrm{A}$ preadipocytes and adipocytes, equal amounts of total RNA from semiconfluent and confluent cultures of $\mathrm{H}$ - 


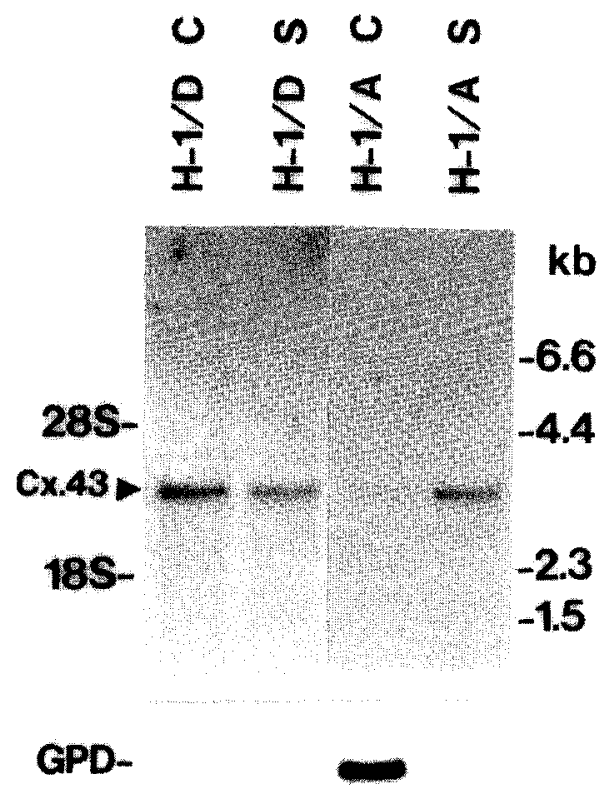

Fig. 1. Analysis of connexin $43(\mathrm{Cx} .43)$ and GPD gene expression during adipocyte differentiation of $\mathrm{H}-1 / \mathrm{A}$ cells.

RNA was extracted from $\cdot H-1 / D$ cells seven days postconfluence $(H-$ 1/D C), semiconfluent $H-1 / D$ cells (H-1/D S), H-1/A cells seven days postconfluence (H-1/A C), and semiconfluent $\mathrm{H}-1 / \mathrm{A}$ cells (H-1/A S) (from left to right). Ten micrograms of total RNA was electrophoresed on each lane. The blot was hybridized with a probe of connexin $43 \mathrm{cDNA}$ described in Materials and Methods. The sizes of connexin 43 and $28 \mathrm{~S}$ and 18S rRNA markers are indicated. The same blot, which was rehybridized with the GPD probe, is shown for reference (32) in the lower panel. The autoradiograms were exposed for 72 hours at $-80^{\circ} \mathrm{C}$ using an intensifying screen.

1/A and $\mathrm{H}-1 / \mathrm{D}$ cells were subjected to blot hybridizations with the connexin 43 probe. H-1/A cells developed many fat droplets in their cytoplasm after reaching confluence, while few fat droplets were detected long after $\mathrm{H}-1 / \mathrm{D}$ cells reached confluence. In the confluent $\mathrm{H}-1 / \mathrm{A}$ culture of an adipocyte state, connexin 43 mRNA levels decreased significantly. On the other hand, no reduction of the RNA levels was observed in H-1/D cells 7 days after confluence (Fig. 1). By contrast, the levels of glycero-monophosphate dehydrogenase (GPD) mRNA clearly increased in confluent $\mathrm{H}$ $1 / \mathrm{A}$ cells as compared with those in the semiconfluent



Fig. 2. Time-course of connexin 43 expression in differentiating $\mathrm{H}$ 1/A cells.

Connexin 43 mRNA levels (open circles) were determined densitometrically from autoradiograms of RNA blot analysis. At the indicated day of postconfluence, RNA was isolated. Five micrograms of total RNA was electrophoresed on each lane. The blots were hybridized with the connexin 43 probe. GPD mRNA levels (closed circles) are shown for reference (32). The amounts of connexin 43 mRNA at confluence (day 0) and GPD mRNA at day 9 postconfluence were regarded as equal to $100 \%$.

culture (32). However, no detectable bands of GPD RNA were observed in either semiconfluent or confluent $\mathrm{H}-1 / \mathrm{D}$ cells. Connexin 43 mRNA specifically decreased during adipocyte differentiation of $\mathrm{H}-1 / \mathrm{A}$ cells rather than as a result of general RNA degradation, as similar amounts of ribosomal RNA from the $\mathrm{H}-1 / \mathrm{A}$ cells at semiconfluence and confluence were detected on each lane. The down-regulation of connexin 43 mRNA seems to be linked with the processes of differentiation rather than with the culture condition, since another differentiation-incompetent subline, H-1/D, did not show any similar alterations in either the differentiation or the connexin 43 regulation.

To investigate the relationship between GPD and connexin 43 expression in detail, we studied the time course of their expression (Fig. 2). Immediately after confluence, connexin 43 mRNA began to decrease, whereas GPD mRNA had yet to appear. On the sixth day after confluence, connexin 43 expression continued to decrease and GPD mRNA began to be induced.

We previously reported that $\mathrm{H}-1 / \mathrm{A}$ preadipocytes in

Fig. 3. Dye transfer in $\mathrm{H}-1 / \mathrm{A}$ cells at semiconfluence $(a, b)$, and at two $(c, d)$ and four days $(e, f)$ postconfluence.

Upper row $(a, b)$ : An H-1/A cell (asterisk) was injected with Lucifer Yellow $\mathrm{CH}$ at the semiconfluent stage. The fluorescent dye was extensively transferred to adjacent cells. The dye spread to three first-order neighboring cells (arrowhead, $3 / 3$ ), and then to second-order neighboring cells (two arrowheads). Middle row (c, d): An H-1/A cell two days postconfluence (asterisk) was injected with Lucifer Yellow CH. The dye spread to one first-order neighboring cell (arrowhead, 1/6), but not to second-order neighboring cells. Lower row (e, f): an H-1/A cell four days postconfluence (asterisk) was injected with Lucifer Yellow $\mathrm{CH}$. No dye transfer to any of the six first-order neighboring cells (arrowheads) was observed $(0 / 6)$. The vacuoles in cell cytoplasm $(b, d, f)$, which was Oil Red O-negative, were not fat droplets. Therefore, these cells containing vacuoles were not adipocytes. These cells could be easily distinguished from true differentiated cells containing fat droplets under a phase contrast microscope. Some of the cells in Fig. $4 \mathrm{f}$ have small fat droplets. (a, c, e) Fluorescent photographs; (b, d, f) phase contrast micrographs of (a), (c) and (e), respectively, $\times 400$. 



Fig. 3. 
vitro communicate with each other via gap junctions while $\mathrm{H}-1 / \mathrm{A}$ adipocytes do not $(30,31)$. To determine whether the down-regulated expression of connexin 43 just after confluence reflects gap-junctional communication, we used the dye-transfer method to assay the communication of postconfluence H-1/A cells (Fig. 3). Gap-junctional communication decreased immediately after confluence (Fig. 4). Accompanying the decrease in communication, cells underwent a marked change in morphology during differentiation, from a flat fibroblastic form to a nearly spherical shape, as shown by the injection of Lucifer Yellow CH (Fig. 3a, c, e). The morphological change was observed before lipid accumula-

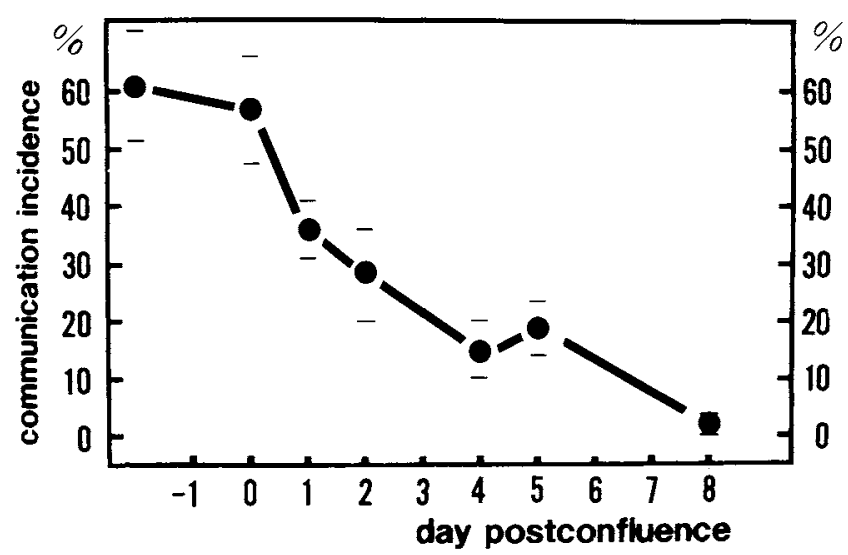

Fig. 4. Intercellular communication capacity of H-1/A cells postconfuence. Intercellular communication was measured by the dye transfer method. At the indicated days of postconfluent culture, Lucifer Yellow $\mathrm{CH}$ solution was microinjected into individual cells using a Narishige micromanipulator. The percentage of dye-transferred first-order neighboring cells was determined 10 minutes later under a fluorescence microscope. Each point represents the mean \pm S.E. of 13 to 37 independent injections.

Fig. 5. Analysis of connexin 43 expression of $\mathrm{H}-1 / \mathrm{A}$ cells at confluence (a) and on day 6 postconfluence (b).

a) $\mathrm{H}-1 / \mathrm{A}$ cells were treated with $200 \mathrm{U} / \mathrm{ml}$ of cachectin/TNF when cells reached confluence. At confluence, no adipocytes were seen in $\mathrm{H}-$ 1/A cells. RNA was extracted from H-1/A cells 12 hours (lane 1), 24 hours (lane 3), and 72 hours (lane 5) after treatment. Lanes 2,4 , and 6 are control cultures (without cachectin/TNF) for lanes 1, 3, and 5, respectively. b) On day $6, \mathrm{H}-1 / \mathrm{A}$ cells were treated with $200 \mathrm{U} / \mathrm{ml}$ or $1,000 \mathrm{U} / \mathrm{ml}$ of cachectin/TNF. Approximately $60 \%$ of $\mathrm{H}-1 / \mathrm{A}$ cells differentiated into adipocytes 6 days postconfluence. RNA was extracted from H-1/A cells after a 12-hour (lane 2), 24-hour (lane 5) or 72-hour (lane 8) exposure to $200 \mathrm{U} / \mathrm{ml}$ of cachectin/TNF, or a 12 hour (lane 3), 24-hour (lane 6) or 72-hour (lane 9) exposure to 1,000 $\mathrm{U} / \mathrm{ml}$ of cachectin/TNF. Lane 1 is a control (without cachectin/TNF) for lanes 2 and 3; lane 4, for lanes 5 and 6 ; and lane 7 , for lanes 8 and 9. The blot was hybridized with the connexin 43 probe first. Then, the blot was dehybridized with boiled $0.01 \%$ SDS, $0.01 \times$ SSC solution 5 times, and rehybridized with the GPD probe ( $b$, bottom). The conditions of hybridization are described in Materials and Methods. Methylene blue-stained 28S and 18S rRNA from the gel is shown (a, lower part; $b$, middle part). tion in the cytoplasm.

To determine connexin 43 and GPD mRNAs during adipocyte differentiation in detail, adipocyte differentiation was inhibited by exposure to cachectin/TNF. Cachectin/TNF is widely known to inhibit adipocyte differentiation $(29,32)$. In order to determine whether cachectin/TNF inhibits the decrease of connexin 43 mRNA, cells were treated with $200 \mathrm{U} / \mathrm{ml}$ of cachectin /TNF when they reached confluence. At confluence, the decrease of connexin 43 expression was reduced by 200



Fig. 5a, b 
$\mathrm{U} / \mathrm{ml}$ of cachectin/TNF (Fig. 5a). GPD, a key enzyme of fat synthesis, was not expressed in either the control or cachectin/TNF-treated cultures. Almost no H-1/A cells differentiated into adipocytes with the addition of cachectin/TNF 12, 24, and 72 hours after confluence. Approximately $20 \%$ of the untreated control cells differentiated into adipocytes 72 hours after confluence while no untreated cells differentiated 12 and 24 hours after confluence. In order to determine whether cachectin /TNF reverses the decrease of connexin 43 transcript in the differentiated H-1/A cells, 6 days after confluence, cells were also treated with $200 \mathrm{U} / \mathrm{ml}$ or $1,000 \mathrm{U} / \mathrm{ml}$ of cachectin/TNF. On the sixth day after reaching confluence, $\mathrm{H}-1 / \mathrm{A}$ expressed both connexin 43 and GPD (Fig. $6 \mathrm{~b})$. Almost $60 \%$ of the untreated $\mathrm{H}-1 / \mathrm{A}$ cells differentiated into adipocytes six days after reaching confluence. In the control culture, connexin 43 expression decreased while the GPD expression increased (Fig. 5b, lanes 1, 4, 7). With $1,000 \mathrm{U} / \mathrm{ml}$ of cachectin/TNF, the decrease of connexin 43 mRNA was again reduced. The amounts of these mRNAs increased or decreased specifically, rather



than as a result of general RNA degradation, for almost the same amounts of ribosomal RNAs of $\mathrm{H}-1 / \mathrm{A}$ cells were detected in the control and cachectin/TNF-treated cultures (Figs. $5 \mathrm{a}$ and $5 \mathrm{~b}$ ). In both the undifferentiated and differentiated $\mathrm{H}-1 / \mathrm{A}$ cells, cachectin/TNF reduced the decrease of connexin 43 transcript.

To determine whether the decrease in connexin 43 cytoplasmic RNA was due to a decreased rate of transcription or certain posttranscriptional events, we also performed nuclear run-off transcription assays. In these experiments, nuclear RNA was radiolabeled by in vitro RNA elongation while reinitiation of RNA synthesis was prevented. The transcriptional rate of connexin 43 genes during differentiation was estimated by measuring the amount of labeled RNA transcribed in nuclei isolated from the $\mathrm{H}-1 / \mathrm{A}$ cells. To demonstrate the specificity of the observed signals, the labeled nuclear RNA was hybridized to pBR 322 . No detectable signals were obtained. The amount of connexin 43-specific transcription was quantitated by hybridization to the excess connexin 43 cDNA bound to a nylon filter. When cells differentiated into adipocytes, the transcriptional rate of connexin 43-specific RNA decreased to $65 \%$ in densitometric analysis, while the transcriptional rate of CSF-1-specific RNA did not change significantly, as described previously (Fig. 6, ref. 32). The transcriptional rate of the actin gene is decreased as well after adipocyte differentiation, as previously reported (32). From these results, we conclude that the decrease of connexin 43-specific cytoplasmic RNA is due, in part to, the change in the transcriptional level. We also attempted to determine the half-life of connexin 43 mRNA in adipocytes, but were unable to do so, since almost no connexin 43 expression was observed in adipocyte RNA even when cells were not exposed to actinomycin D.

\section{DISCUSSION}

With the electron microscope, gap junctions are observed between marrow stromal cells in vivo (36). In adherent cells of long-term bone marrow culture and stromal cell lines, in vitro communication between cells via gap junctions has been observed by electron microscopy and with the dye-transfer method $(30,38)$. In this study, marrow stromal cells were found to express connexin 43 but not connexin 32 . Connexin 43 is a heartmuscle-type connexin , and is expressed in heart, ovary, kidney, uterus and lens (4). In contrast, connexin 32 is expressed in liver, kidney, brain, and stomach (24). The type of connexin is the same in marrow stroma irrespective of differentiation capability, i.e., in adipocytes, osteocytes and myotubes. The myotube differentiation of KUSA cells is consistent with the fact that KUSA cells expressed the heart-muscle-type connexin (33).

Gap-junctional communication is regulated by vari- 
ous cytoplasmic factors such as protein kinase $C$, cAMP, $\mathrm{Ca}^{+}$ion, and $\mathrm{pH}$ (8, see also reviews, ref. 21). These factors change the communication level by modulating the gap-junctional structure directly or indirectly. The phosphorylated state of gap-junctional protein is related to junctional communication (22). Crystallization of the gap-junctional component is associated with junctional uncoupling in an ultrastructural study (14). The radial displacement of connexin at the cytoplasmic end is thought to result in closing of the gap-junctional channel (34). In the H-1/A cells used in this study, gap-junctional communication was reduced after adipocyte differentiation. Our time-kinetic study of connexin 43 expression clearly demonstrated that the loss of gap-junctional communication after the adipocyte differentiation of $\mathrm{H}-1 / \mathrm{A}$ cells is explained by changes in the connexin 43 mRNA levels, not by those in the the protein level or phosphorylated state.

The down-regulation of connexin 43 expression began prior to the switching-on of the lipogenic enzyme gene, and is, therefore, one of the early events in the differentiation process. Just after confluence, cell growth is arrested (23) and cell shape is changed in $\mathrm{H}$ $1 /$ A cells. Therefore, down-regulated expression of connexin 43 was accompanied by changes in cell morphology and cell growth at the early stage of differentiation, independent of lipid accumulation. These changes in connexin 43 during differentiation are similar to those in cytoskeletal proteins such as actin and tubulin (28, 32). The change in cell morphology during adipocyte differentiation is independent of lipid accumulation (20) and is accompanied by alterations in cytoskeletal proteins (28).

Various levels of gene control have been reported in eukaryotic cells during differentiation (7). The quantitative data obtained by nuclear run-off transcriptional assays clearly showed that the decreased transcriptional rate of connexin 43 gene during adipocyte differentiation is similar to that of cytoskeleton (actin) genes (32). In contrast, the reduction of transcripts of CSF-1, a hematopoietic growth factor, after adipocyte differentiation is due to a posttranscriptional event rather than a decreased rate of transcription; connexin 43 and CSF-1 mRNAs are down-regulated by different mechanisms during the differentiation of $\mathrm{H}-1 / \mathrm{A}$ cells.

In vivo, marrow adipocytes, which have a basement membrane around the cells, do not have gap junctions with neighboring cells, while most fibroblasts do (36). These ultrastructural findings are consistent with results in studies indicating that stromal cells lose their gapjunctional communication after adipocyte differentiation.

Acknowledgements. We wish to especially thank Drs. T. Maruyama, S. Christensen, Y. Watanabe, T. Takano, J. Miyauchi and K.
Tachibana for their helpful discussion, Dr. D.L. Paul for connexin 43 and connexin 32 cDNA, Drs. B.M. Spiegelman for GPD cDNA and N. Davidson for actin DNA, and Dr. K. Harigaya for providing a cell line. We also wish to thank Messrs. Kusakari and Abe for their excellent technical assistance and Mr. Takeichi for photographs. This work was supported by Grants-in-Aid for Scientific Research 02857062 and 03670182 from the Ministry of Education, Science and Culture of Japan.

\section{REFERENCES}

1. Akasaka, Y., Fuimoto, J., Harigaya, K., ЕNomoto, Y., Watanabe, Y., and Hata, J-I. (1991). Monoclonal antibody against bone marrow stromal cells. Its production and characterization. Acta Pathol. Jpn., 41: 499-506.

2. Allen, T.D. and Dexter, T.M. (1983). Long term bone marrow cultures: An ultrastructural review. Scan. Electr. Micr., 1983/IV: 1851 .

3. AzARnia, R. and Russel, T.R. (1985). Cyclic AMP effects on cell-to-cell junctional membrane permeability during adipocyte differentiation of 3T3-L1 fibroblasts. J. Cell Biol., 100: 265269.

4. Beyer, E.C., Paul, D.L., and Goodenough, D.A. (1987). Connexin 43: a protein from rat heart homologous to a gap junction protein from liver. J. Cell Biol., 105: 2621-2629.

5. Chirgwin, J.M., Przbyla, A.E., MacDonald, R.J., and RUTTER, W.J. (1979). Isolation of biological active ribonucleic acid from sources enriched in ribonucleases. Biochemistry, 18: 5294-5299.

6. Cohen, G.I., Greenberger, J.S., and Canellos, G.P. (1982). Effects chemotherapy and irradiation on interactions between stromal and hemopoietic cells in vitro. Scan. Electr. Micr., 1982/I: 359.

7. DaRnell, Jr. J.E. (1982). Variety in the level of gene control in eukaryotic cells. Nature, 297: 365-370.

8. ENOMOTO, T. and YAMASAKI, H. (1985). Rapid inhibition of intercellular communication between BALB $/ \mathrm{c} 3 \mathrm{~T} 3$ cells by diacylglycerol, a possible endogenous functional analogue of phorbol esters. Cancer Res., 45: 3706-3710.

9. Feinberg, A.P. and Vogeistein, B. (1983). A technique for radiolabeling DNA restriction endonuclease fragments to high specific activity. Anal. Biochem., 132: 6-13.

10. Gimlich, R.L., Kumar, N.M., and Gilula, N.B. (1988). Sequence and developmental expression of mRNA coding for a gap junction protein in Xenopus. J. Cell Biol., 107: 1065-1073.

11. Gimlich, R.L., Kumar, N.M., and Gilula, N.B. (1990). Differential regulation of the levels of three gap junction mRNAs in Xenopus embryos. J. Cell Biol., 110: 597-605.

12. Groudine, M., Peretz, M., and Weintraub, H. (1981). Transcriptional regulation of hemoglobin switching on chicken embryo. Mol. Cell. Biol., 1: 281-288.

13. Harigaya, K., Cronkite, E.P., Miller, M.E., and SHADDUCK, R.K. (1981). Murine bone marrow cell line producing colony-stimulating factor. Proc. Natl. Acad. Sci. USA, 78: 6963-6966.

14. Hirokawa, N. and Heuser, J. (1982). The inside and outside of gap-junction membranes visualized by deep etching. Cell, 30: 395-406.

15. Hu, M.C-T., Sharp, S.B., and Davidson, N. (1986). The complete sequence of the mouse skeletal alpha-actin gene reveals several conserved and inverted repeat sequences outside of the protein-coding region. Mol. Cell. Biol., 6 (1): 15-25. 
16. Kanno, Y. and Loewenstein, W.R. (1964). Intercellular diffusion. Science, 143: 959-960.

17. Kanno, Y. and Loewenstein, W.R. (1966). Cell-to-cell passage of large molecules. Nature, 212: 629-630.

18. KanNo, Y. (1985). Modulation of cell communication and carcinogenesis. Jpn. J. Physiol., 35: 693-707.

19. Kumar, N.M. and Gilula, N.B. (1986). Cloning and characterization of human and rat liver cDNA coding for a gap junction protein. J. Cell Biol., 103: 767-776.

20. KURi-Harcuch, W., Wise, L.S., and Green, H. (1978). Interruption of the adipose conversion of 3T3 cells by biotin deficiency: differentiation without triglyceride accumulation. Cell, 14: 53-59.

21. LOEWENSTEIN, W.R. (1981). Junctional intercellular communication: the cell-to-cell membrane channel. Physiol. Rev., 61: 829-913.

22. Musil, L.S., Cunningham, B.A., Edelman, G.M., and Goodenough, D.A. (1990). Differential Phosphorylation of the gap junction protein connexin 43 in junctional communication-competent and -deficient cell lines. J. Cell Biol., 111: 2077-2088.

23. Nakamura, M., Harigaya, K., and Watanabe, Y. (1985). Correlation between production of colony-stimulating activity (CSA) and adipose conversion in a murine marrow-derived preadipocyte line (H-1/A). Proc. Soc. Exp. Biol. Med., 179: 283287.

24. PAUL, D.L. (1986). Molecular cloning of cDNA for rat liver gap junction protein. J. Cell Biol., 103: 123-134.

25. Sasaki, Y., Shiba, Y., Hirono, C., Kanno, Y., Takeuchi, T., and UMEZAWA, K. (1989). Herbimycin A suppresses the reduction of gap-junctional intercellular communication induced by tumor-promoting phorbol ester in 3T3-L1 cells. Jpn. J. Cancer Res., 80: 855-860.

26. Shiba, Y., Sasaki, Y., Hirono, C., and Kanno, Y. (1989). Close relationship between modulation of serum-induced stimulation of DNA synthesis and changes in gap-junctional intercellular communication in quiescent 3T3-L1 cells caused by cyclic AMP and the tumor-promoting phorbol ester TPA. Exp. Cell Res., 185: 535-540.

27. Shiba, Y., SASAKI, Y., and KanNo, Y. (1990). Inhibition of gap-junctional intercellular communication and enhanced binding of fibronectin-coated latex beads by stimulation of DNA synthesis in quiescent 3T3-L1 cells. J. Cell. Physiol., 145: 268-273.

28. Spiegelman, B.M. and Farmer, S.R. (1982). Decrease in tubulin and actin gene expression prior to morphological differentiation of 3T3 adipocytes. Cell, 29: 53-60.

29. Torti, F.M., Dieckmann, B., Beutler, B., Cerami, A., and RINGOLD, G.M. (1985). A macrophage factor inhibits adipocyte gene expression: an in vitro model of cachexia. Science, 229: $867-869$.

30. Umezawa, A., Harigaya, K., and Watanabe, Y. (1987). Bone marrow s cells lose their gap-junctional communication in vitro during the differentiation to adipocytes. Hematology Rev. Comm., 1: 277-283.

31. Umezawa, A., Harigaya, K., Abe, H., and Watanabe, Y. (1990). Gap-junctional communication of marrow stromal cells is resistant to irradiation in vitro. Exp. Hematol., 18: 1002-1007.

32. Umezawa, A., Tachibana, K., Harigaya, K., Kusakari, S., Kato, S., Watanabe, Y., and Takano, T. (1991). Colonystimulating factor 1 is down-regulated during the adipocyte differentiation of H-1/A marrow stromal cells and induced by cachectin/tumor necrosis factor. Mol. Cell. Biol., 11(2): 920927.

33. Umezawa, A., Maruyama, T., Segawa, K., Shadduck, R.K., WAHEED, A., and HaTA, J-I. (1992). Multipotent marrow stromal cell line is able to induce hematopoiesis in vivo. J. Cell. Physiol., 151: 197-205.

34. UnVIN, P.N.T. and ZAMPIGHI, G. (1980). Structure of the junction between communicating cells. Nature, 283: 545-549.

35. Warner, A.E., Guthrie, S.C., and Gilula, N.B. (1984). Antibodies to gap-junctional protein selectively disrupts junctional communication in the early amphibian embryo. Nature (Lond.), 311: 127-131.

36. WatanABE, Y. (1985). Fine structure of bone marrow stroma. Acta Haematol. Jpn., 48 (8): 1688-1700.

37. Yamazaki, K., Roberts, R.A., SPOONCER, E., DeXTer, T.M., and Allen, T.D. (1989). Cellular interactions between 3T3 cells and interleukin-3-dependent multipotent haematopoietic cells: a model system for stromal-cell-mediated haematopoiesis. J. Cell. Physiol., 139: 301-312.

38. YAMAZAKI, K. (1988). Sl/Sld mice have an increased number of gap junctions in their bone marrow stromal cells. Blood Cells, 13: $421-431$.

39. Zhang, J.-T. and Nicholson, B.J. (1989). Sequence and tissue distribution of a second protein of hepatic gap junctions, Cx26, as deduced from its cDNA. J. Cell Biol., 109: 3391-3402.

(Received for publication, November 12, 1991

and in revised form, April 7, 1992) 